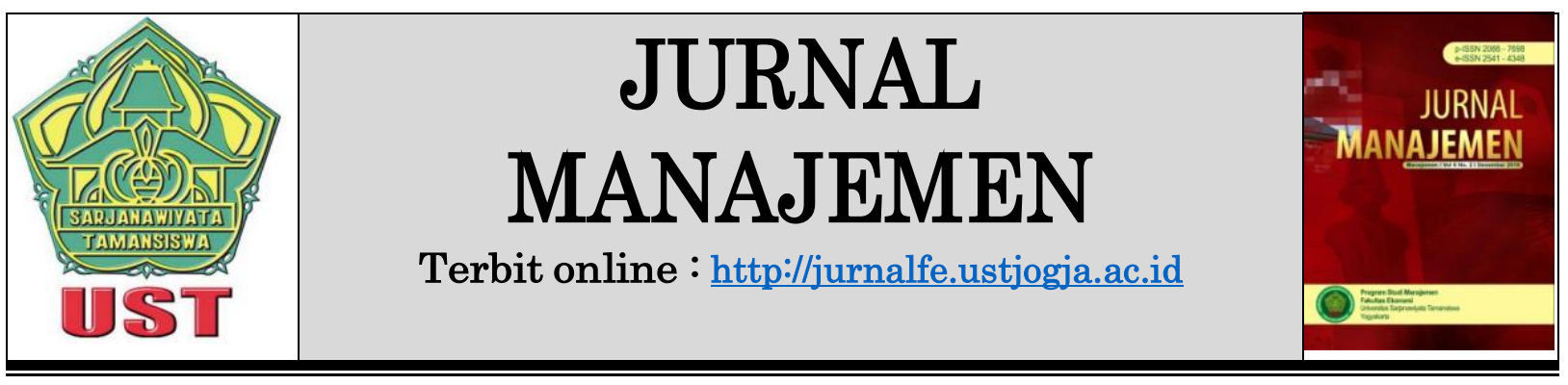

\title{
KETERLIBATAN KELUARGA DALAM MANAJEMEN, KEPEMILIKAN KELUARGA, DAN KINERJA PERUSAHAAN: BUKTI EMPIRIS DARI BURSA EFEK INDONESIA
}

\author{
Maria Eka Prasetya Ningsih ${ }^{1}$ \\ Perminas Pangeran ${ }^{2}$
}

${ }_{1,2}$ Fakultas Bisnis, Universitas Kristen Duta Wacana, Yogyakarta Korespondensi: mariaprasetya19@gmail.com dan perminas@ukdw.ac.id

\begin{tabular}{ll}
\hline Informasi Naskah & Abstrak \\
\hline Diterima: & The objective of this study is to examine the effect \\
09 Oktober & of family involvement in firm's management and family \\
Revisi: & ownership on financial performance. The sample of this \\
11 Oktober & study are 8 family firms that listed in Indonesian stock \\
Terbit: & exchange during 2012-2015. This research used \\
16 Desember & multiple regression technique. \\
\hline Kata Kunci: Family & The results of this study indicated that family \\
Ownership, Family & ownership had a negative effect on campanies financial \\
Involvement, & performance, while the family involvement in the firm's \\
Financial & management had no significant effect on campanies \\
Performance & financial performance
\end{tabular}

\section{PENDAHULUAN}

Perusahaan keluarga merupakan fenomena tersendiri dalam dunia bisnis. Hasil penelitian menunjukan bahwa $65,14 \%$ perusahaan Indonesia dikendalikan oleh pemilik yang memiliki kepemilikan mayoritas dan $66,45 \%$ perusahaan dimiliki oleh individu atau kelompok anggota keluarga, (Rusmin et al., 2011). Perusahaan keluarga juga memiliki andil yang cukup signifikan bagi pendapatan negara (Widjaja dan Mustamu, 2012). Di Indonesia, perusahaan keluarga dapat memberi kontribui antara $45 \%$ sampai $70 \%$ pada Produk Domestik Kotor (GDP) dan mampu menyerap banyak tenaga kerja (Glassop dan Waddell, 2005 dalam Widjaja dan Mustamu, 2012). Perusahaan keluarga adalah sebuah perusahaan yang memiliki pengelolaan dan pola transformasi perusahaan keluarga yang unik dan tidak dimiliki oleh perusahaan pada umumnya. Kinerja keuangan dan nilai pasar perusahaan merupakan dua hal yang sangat penting bagi kelangsungan perusahaan, agar mampu berkembang dan bersaing dengan perusahaan lainnya. Keunikan bagi perusahaan keluarga, 
pencapaian profit harus terus berkembang seiring dengan semakin harmonisnya keluarga, dengan demikian bisnis keluarga dapat berhasil.

Sementara itu, ciri perusahaan keluarga biasanya ditandai dengan adanya anggota keluarga yang memiliki jabatan di jajaran top manajemen perusahaan, seperti jabatan sebagai dewan direksi dan jabatan sebagai dewan komisaris. Keterlibatan keluarga pada manajemen dapat mempengaruhi kinerja perusahaan. Berdasarkan perspektif teori alignment effect menjelaskan bahwa kepemilikan keluarga dapat meningkatkan kinerja perusahaan, sehingga dengan adanya kinerja perusahaan yang meningkat diharapkan dapat meningkatkan keuntungan perusahaan. Sebaliknya, perspektif teori entrenchment effect menjelaskan bahwa kepemilikan keluarga dapat menurunkan kinerja perusahaan, sehingga adanya kepemilikan keluarga dapat mengakibatkan pada kerugian perusahaan. Dengan demikian, kajian tentang pengaruh kepemilikan keluarga terhadap kinerja perusahaan menjadi sangat penting.

Penelitian ini akan mengikuti penelitian yang sebelumnya telah dilakukan oleh Kowalewski et al, 2010. Perbedaan penelitian ini dengan penelitian sebelumnya, penelitian ini menggunakan variabel Tobin $Q$ sebagai ukuran kinerja perusahaan, dan penelitian ini dilakukan di pasar modal Indonesia, sedangkan penelitian sebelumnya dilakukan di pasar modal Polandia dan mengunakan variabel ROA dan ROE sebagai ukuran kinerja perusahaan. Penelitian ini menggunakan perusahaan milik keluarga yang terdaftar di Bursa Efek Indonesia pada periode tahun 2010-2013, yaitu perusahaan manufaktur sektor Industri dasar dan kimia. Penelitian ini menggunakan perusahaan milik keluarga sebagai pemilik saham dan berperan sebagai CEO. Pada penelitian ini fokus pada variabel keterlibatan Keluarga Aktif (KKA) dan Kepemilikan Keluarga (KK) dan kinerja keuangan perusahaan yang di ukur melalui Tobin Q.

Tujuan Penelitian, untuk menguji pengaruh keterlibatan keluarga dalam manajemen dan kepemilikan keluarga terhadap kinerja keuangan perusahaan. Penelitian ini diharapkan dapat menambah penjelasan berkaitan dengan variabel keterlibatan keluarga dalam manajemen dan kepemilikan keluarga terhadap kinerja keuangan perusahaan. Bagi perusahaan, hasil penelitian diharapkan dapat menjadi suatu masukan yang bermanfaat bagi perusahaan dalam rangka meningkatkan kinerja keuangan perusahaan.

\section{KAJIAN PUSTAKA DAN HIPOTESIS Teori Keagenan}

Teori keagenan (agency theory) pertama dikemukan oleh Jensen dan Meckling (1976). Jensen dan Meckling mendifinisikan agency relationship sebagai suatu kontrak dimana satu atau lebih orang (principal (s)) mengikut serta orang lain (the agent) untuk melaksanakan beberapa pelayanan atas nama mereka dan principal mendelegasikan beberapa otoritas pembuatan keputusan kepada agen tersebut.Teori Keagenan mendasarkan pada asumsi bahwa agen tidak selalu bertindak atas kepentingan principal. Agen berusaha memaksimumkan kepentingan dirinya. Hal ini didasarkan pada sifat dasar manusia yang mendahulukan kepentingan pribadi dibandingkan kepentingan 
orang lain (self-interest behavior). Sifat inilah yang memicu timbulnya masalah keagenan, manakala perusahaan semakin besar, sehingga kepemilikannya dan kontrol manajeman dilakukan secara terpisah. Perbedaan kepentingan ini harus diperhatikan secara bersama antara manajer dan pemilik demi kebaikan nilai perusahaan kedepannya.

\section{Efek Entrenchment}

Claessens et al. (2002) dan Fan dan Wong (2002) menyatakan pemegang saham yang memiliki hak kontrol yang lebih tinggi dibandingkan hak arus kasnya dalam kepemilikan piramida akan menimbulkan efek entrenchment. Pada dasarnya entrenchment effect tidak selalu bersifat negatif. Efek entrenchment yang negatif didefinisikan sebagai kemampuan pemegang saham pengendali akhir untuk menentukan kebijakan operasional perusahaan sesuai dengan kepentingan pribadinya walaupun harus mengorbankan kepentingan pemegang saham dan pemangku kepentingan lainnya. Melalui penjelasan tersebut, dapat disimpulkan bahwa Pemegang saham pengendali dapat memanfaatkan hak kontrolnya yang tinggi untuk mengambil keuntungan dari perusahaan tanpa menanggung biaya yang tinggi atau biasa dikenal sebagai tindakan ekspropriasi (Fan dan Wong (2002). Tindakan ekspropriasi yang dapat dilakukan oleh pemegang saham pengendali akhir dapat berupa tindakan untuk melakukan transakasi yang menguntungkan pemegang saham pengendali akhir, transaksi pihak berelasi antar perusahaan yang berada dalam pengendalian yang sama oleh pemegang saham pengendali akhir sehingga tidak memaksimalkan profit, atau penurunan pembagian dividen kepada pemegang saham non-pengendali (Claessens et al., 1999). Hal ini mengakibatkan terjadinya konflik keagenan antara pemegang saham pengendali akhir dengan pemegang saham non-pengendali dalam mekanisme kepemilikan piramida. La Porta et al. (1999) menjelaskan bahwa mekanisme kepemilikan piramida merupakan mekanisme yang lebih efektif bagi pemegang saham mayoritas dalam meningkatkan kontrol terhadap suatu perusahaan secara tidak langsung. Mekanisme kepemilikan piramida cenderung terdapat pada perusahaan-perusahaan di negara yang memiliki tingkat perlindungan pemegang saham yang rendah (La Porta et al., 1999). Claessens et al. (2002) menyatakan bahwa terdapat perbedaan hak kontrol dan hak arus kasa yang signifikan pada perusahaan-perusahaan di Asia Timur dan kontrol tersebut diperkuat dengan mekanisme kepemilikan piramida. Berdasarkan sampel penelitian yang dilakukan oleh Claessens et al. (2000), Negara Indonesia merupakan negara yang memiliki tingkat penggunaan mekanisme kepemilikan piramida yang paling tinggi yaitu sebesar $66.9 \%$ dari perusahaan sampel di Indonesia. Lebih lanjut, Claessen et al. (2002) menemukan bahwa tindakan ekspropiasi oleh pemegang saham pengendali akhir paling tinggi dilakukan oleh perusahaan-perusahaan di Indonesia dibandingkan dengan delapan negara lain yang menjadi sampel penelitiannya.

\section{Efek Alignment}

Cara untuk memitigasi efek dari entrenchment negatif adalah melalui peningkatkan jumlah kepemilikan pemegang saham pengendali akhir (Fan dan Wong, 2002). Melalui peningkatan kepemilikan tersebut, pemegang saham 
pengendali akan memiliki hak arus kas yang semakin tinggi juga. Peningkatkan hak arus kas akan menyebabkan semakin tingginya biaya yang harus ditanggung oleh pemegang saham pengendali akhir ketika melakukan tindakan ekspropiasi untuk mendapatkan keuntungan pribadi (Claessen et al, 2002 ; Fan dan Wong, 2002). Fenomena ini biasa dikenal sebagai efek alignment (Fan dan Wong, 2002). Melalui hal tersebut, pemegang saham pengendali menjadi kurang termotivasi untuk melakukan tindakan ekspropriasi dan menghindari kerugian perusahaan. Oleh karena itu, alignment effect dapat memberikan keuntungan kepada investor dan pemangku kepentingan lainnya. Lebih lanjut, cara lain untuk memitigasi permasalahan keagenan tersebut adalah dengan penerapan sistem tata kelola perusahaan yang baik dan efektif (Fan dan Wong, 2002).

\section{PENGEMBANGAN HIPOTESIS}

\section{Keterlibatan Keluarga Dalam Manajemen dan Kinerja Keuangan}

Keterlibatan Keluarga dalam managemen adalah salah satu karakteristik yang melekat dalam perusahaan keluarga, yaitu dengan adanya keinginan agar kepemimpinan perusahaan dipegang oleh anggota keluarga. Karakter ini secara umum bertumpu pada peran keluarga dalam sebuah perusahaan keluarga. Keluarga lebih suka apabila perusahaan yang dimilikinya dipimpin oleh anggota keluarganya, karena rasa percaya yang tinggi antar sesama anggota keluarga. Perusahaan keluarga yang dipimpin oleh keluarga memiliki kecenderungan dapat meminimalkan atau bahkan menghilangkan adanya masalah keagenan.

Pemimpin yang berasal dari anggota keluarga tentunya akan berusaha keras untuk mensejahterakan pemegang saham, dimana pemegang saham tersebut adalah keluarganya sendiri. Keberadaan CEO dan manajemen puncak yang berasal dari keluarga menunjukkan adanya manajemen keluarga yang aktif sehingga memudahkan keluarga dalam mengontrol perusahaan agar sesuai dengan kepentingan pemilik. CEO dan manajemen puncak yang dipegang oleh anggota keluarga dapat meningkatkan kinerja perusahaan karena mereka akan menjaga perusahaan dan mengidentifikasikan diri mereka dengan perusahaan. CEO yang berasal dari keluarga merasa bahwa perusahaan adalah kepanjangan tangan mereka sehingga kesehatan perusahaan menjadi perhatian utama mereka karena kinerja perusahaan berhubungan erat dengan kesejahteraan mereka secara pribadi. Hasil penelitian Andres (2008), menunjukkan bahwa apabila keluarga hanya bertindak sebagai pemegang saham dan tidak aktif dalam pengelolaan perusahaan, maka kinerja perusahaan tersebut buruk. Namun jika anggota keluarga berpartisipasi dalam kegiatan manajerial, maka kinerja perusahaan akan meningkat.

$\mathrm{H}_{1}$ : Keterlibatan keluarga dalam manajemen berpengaruh positif terhadap kinerja perusahaan

\section{Kepemilikan Keluarga dan Kinerja Keuangan}

Perusahaan modern seringkali memisahkan antara kepemilikan dan pengelolaan dalam perusahaan. Pemisahan ini kemudian menimbulkan konflik antara manajer sebagai pengelola perusahaan dengan investor sebagai 
pemegang saham atau pemilik perusahaan (Fama dan Jensen, 1983; Jensen dan Meckling, 1976). Masalah keagenan merupakan perbedaan kepentingan antara pemegang saham (principal) dengan manajer (agent). Dalam menghadapi masalah keagenan, perusahaan membutuhkan biaya untuk mengatasinya, yang disebut dengan biaya keagenan (agency cost). Biaya keagenan adalah biaya yang harus dikeluarkan oleh perusahaan karena adanya manajer yang bertindak tidak sesuai dengan keinginan pemegang saham dalam memaksimalkan kesejahteraan pemegang saham. Namun, pada perusahaan yang kepemilikan sahamnya mayoritas dimiliki oleh keluarga biasanya dikontrol oleh keluarga pemilik perusahaan.

Menurut Jensen dan Meckling (1976), perusahaan dengan struktur tersebut akan dapat meminimalkan atau menghilangkan masalah dan biaya keagenan. Biaya dan masalah keagenan tidak akan muncul karena pemilik dan manajemen perusahaan adalah pihak yang sama dan tidak akan terjadi perbedaan kepentingan, sehingga biaya keagenan yang muncul untuk monitoring akan sedikit atau bahkan tidak ada. Struktur kepemilikan yang terkonsentrasi pada keluarga, biasanya terlihat dari adanya anggota keluarga yang memiliki jabatan di jajaran top managemen perusahaan. Selain itu, dalam perusahaan yang kepemilikannya terkonsentrasi pada keluarga, biasanya terjadi transfer pengalaman dan pengetahuan dari generasi satu ke generasi penerusnya.

Apabila generasi penerus ini tumbuh dan sudah lama berada dalam perusahaan akan menciptakan hubungan yang penuh rasa kepercayaan dengan karyawan dan hubungan yang berorientasi jangka panjang dengan para pemasok dan pihak eksternal lainnya. Menurut Andres (2008), perusahaan keluarga dapat menciptakan kepercayaan dan loyalitas pekerja sehingga akan menurunkan biaya rekrutmen dan pergantian karyawan dalam perusahaan. Keunggulan perusahaan keluarga dibandingkan perusahaan non keluarga bisa ditinjau dari dua aspek, yaitu aspek kepemilikan dan aspek manajemen. Dari sudut pandang kepemilikan, keunikan perusahaan keluarga adalah mayoritas aset perusahaan dipegang oleh anggota keluarga. Dari sisi manajemen, posisi CEO atau manajemen puncak perusahaan keluarga didominasi oleh anggota keluarga. Keberadaan pendiri dalam perusahaan dalam waktu yang lama menimbulkan suatu keunggulan kompetitif tersendiri bagi perusahaan keluarga. Pertama, lamanya kepemilikan keluarga dalam perusahaan telah menciptakan learning curve bagi pemilik dalam memonitor kinerja karyawannya. Kedua, keluarga cenderung mempertahankan investasi yang lebih panjang dibandingkan pemegang saham lainnya. Perusahaan keluarga juga senantiasa berupaya melakukan investasi secara efisien karena perusahaan keluarga memiliki keinginan yang kuat untuk bisa mewariskan perusahaan mereka kepada generasi selanjutnya.

\section{$\mathrm{H}_{2}$ : Kepemilikan keluarga berpengaruh positif terhadap kinerja perusahaan}

\section{METODE PENELITIAN}

\section{Metode Pengumpulan Data}

Metode pengumpulan data pada penelitian ini adalah dengan metode dokumentasi, yaitu penggunaan data yang berasal dari dokumen-dokumen yang sudah ada. Hal ini dilakukan dengan cara melakukan penelusuran dan 
pencatatan informasi yang sudah ada pada data sekunder berupa laporan tahunan (annual report), Indonesia Capital Market Directory (ICMD). Data yang digunakan merupakan data dari perusahaan keluarga manufaktur, sektor Industri dasar dan kimia, yang terdaftar di Bursa Efek Indonesia (BEI) periode 2010-2013.

\section{Sampel Penelitian}

Populasi yang digunakan dalam penelitian ini adalah perusahaan keluarga manufaktur, sektor Industri dasar dan kimia, yang terdaftar di Bursa Efek Indonesia (BEI) selama periode 2010-2013. Sedangkan pengambilan sampel dilakukan dengan menggunakan metode purposive sampling yakni pengambilan sampel dengan kriteria atau batasan-batasan tertentu. Adapun pertimbangan yang diambil berdasarkan tujuan penelitian yaitu sampel harus memenuhi kriteria sebagai berikut: 1) Penelitian dilakukan tehadap perusahaan keluarga. Perusahaan keluarga dipilih berdasarkan nama belakang yang sama (Mishra and McConaughy, 1999). Meskipun mungkin kurang akurat tetapi hal ini harus dilakukan untuk memastikan perusahaan tersebut adalah perusahaan keluarga. 2). Perusahaan tersebut terdaftar di BEI selama periode 2012-2015. 3) Perusahaan keluarga yang menerbitkan laporan keuangan yang lengkap.Terdapat perwalian anggota keluarga yang menjabat sebagai CEO atau dewan direksi perusahaan tersebut (Villalonga dan Amit, 2006). 4) Terdaftar pada sektor industri dasar dan kimia.

\section{Definisi Operasional Variabel Variabel Dependen}

Variabel dependen atau terikat adalah variabel yang menjadi pusat atau inti dari sebuah penelitian yang diduga dipengaruhi oleh variabel independen. Variabel dependen dalam penelitian ini adalah Kinerja Keuangan Perusahaan yang diukur dengan rumus Tobin $Q$. Di dalam penggunaannya, Tobin $Q$ mengalami modifikasi. Modifikasi Tobinm $Q$ versi Chung dan Pruitt (1994) telah digunakan secara konsisten karena disederhanakan diberbagai simulasi permainan. Menurut mereka, modifikasi versi ini secara statistik kira-kira mendekati Tobin's q asli dan menghasilkan perkiraan 99,6\% dari formulasi aslinya yang digunakan oleh Lindenberg dan Ross (1981). Tobin's $q$ mampu meringkas informasi yang akan datang yang relevan dengan keputusan investasi perusahaan. Selain itu, analisis Tobin's $q$ merupakan indikator yang fokus pada nilai pasar perusahaan, sehingga sangat bermanfaat jika dilihat dari perspektif investor. Formulasi rumusnya sebagai berikut:

$$
\mathrm{Q}=(\mathrm{MVS}+\mathrm{D}) / \mathrm{TA}
$$

\section{Dimana:}

$\mathrm{Q} \quad=$ Tobin's $q$

MVS = Market value of all outstanding shares.

$\mathrm{D} \quad=$ Debt.

TA = Firm's asset's.

Market value of all outstanding shares (MVS) merupakan nilai pasar saham 
yangdiperoleh dari perkalian jumlah saham yang beredar dengan harga saham (Outstanding Shares* Stock Price). Debt merupakan besarnya nilai pasar hutang, dimana nilai ini dapat dihitung dengan menggunakan persamaan sebagai berikut:

$\mathrm{D}=(\mathrm{AVCL}-\mathrm{AVCA})+\mathrm{AVLTD}$

Dimana:

AVCL = Accounting value of the firm's CurrentLiabilities. = Short Term Debt + Taxes Payable.

AVLTD = Accounting value of the firm's LongTerm Debt. = Long Term Debt.

AVCA = Accounting value of the firm's CurrentAssets. $=$ Cash + Account Receivable +Inventories .

Analisis Tobin Q, yang merupakan salah satu indikator yang dapat digunakan untuk mengukur kinerja dan nilai perusahaan berdasarkan perspektif investor. Menurut Chung and Pruitt (1994), analisis ini dapat menjelaskan sejumlah fenomena perusahaan yang berbeda-beda, yang diantaranya (a) perbedaan cross-sectional dalam keputusan investasi dan diversifikasi, (b) hubungan antara kepemilikan ekuitas manajerial dan nilai perusahaan, (c) hubungan antara performa manajemen, keuntungan penawaran tender, peluang investasi, dan respon penawaran tender, dan (d) kebijakan dalam hal keuangan, dividen, dan kompensasi.

Nilai Tobin's q menggambarkan suatu peluang investasi yang dimiliki perusahaan atau potensi pertumbuhan perusahaan. Sesuai dengan rumusnya, nilai Tobin $Q$ didapatkan dari penjumlahan nilai pasar saham dari seluruh saham yang beredar (market value of all outstanding shares) dengan nilai pasar hutang (market value of all debt) yang kemudian dibandingkan dengan nilai seluruh modal yang ditempatkan dalam kapasitas produksi (replacement value of all production capacity). Melalui rumus dan definisi tersebut, maka terlihat jelas bahwa Tobin $Q$ menitikberatkan analisisnya pada nilai pasar yang dimiliki perusahaan.

Dalam pengukuran menggunakan Tobin $Q$, standar yang ditetapkan sebagai nilai acuan adalah satu. Standar ini ditetapkan karena pada dasarkan Tobin $Q$ menyatakan bahwa nilai pasar suatu perusahaan seharusnya sama dengan nilai aktivanya, yang diasumsikan disini adalah sama dengan satu. Jika nilai Tobin $Q$ dari suatu perusahaan besarnya lebih dari satu, maka perusahaan akan dianggap baik oleh pasar, karena hal ini menandakan nilai pasar perusahaan lebih besar dari aktiva perusahaan yang tercatat. Namun, jika sebaliknya, maka perusahaan akan dianggap tidak terlalu baik oleh pasar karena pencatatan nilai aktivanya melebihi nilai pasar perusahaan.

\section{Variabel Indepanden}

Variabel Indepanden Pengaruh keterlibatan keluarga dalam manjemen dan kepemilikan keluarga yang diukur dengan rumus:

Keterlibatan Keluarga dalam Manajemen (KKA). Keterlibatan Keluarga adalah jumlah keluarga yang menduduki posisi di dewan direksi dan komisaris 
di satu perusahaan keluarga. Keterlibatan keluarga di ukur dengan :

$$
\mathrm{KKA}=\frac{\text { Jumlah Direksi yang berasal dari Keluarga }}{\text { Jumlah seluruh Direksi }} X 100 \%
$$

Kepemilikan Keluarga (KK). Kepemilikan keluarga didefinisikan sebagai kepemilikan dari individu atau suatu keluarga dan kepemilikan bukan perusahaan publik, negara, ataupun institusi keuangan. Kepemilikan Keluarga (KK) diukur dengan menggunakan:

$$
\mathrm{KK}=\frac{\epsilon S K}{\epsilon S T} \boldsymbol{x} 100 \%
$$

\section{Dimana:}

SK = Jumlah Saham keluarga

ST $=$ Jumlah Saham total

\section{Model Empiris}

Model statistik yang digunakan dalam penelitian ini adalah analisis regresi berganda. Regersi berganda digunakan untuk memecahkan kasus yang memiliki satu variabel dependen dengan beberapa variabel independen. Pada penelitian ini digunakan dua variabel bebas yang meliputi keterlibatan keluarga dalam manajemen dan kepemilikan keluarga, serta satu variabel terikat yaitu kinerja keuangan perusahaan. Persamaan umum regresi berganda dalam penelitian ini adalah sebagai berikut:

\section{$\mathrm{TQ}=\mathrm{a}+\mathrm{B1KKA}+\mathrm{B2KK}+\mathrm{e}$}

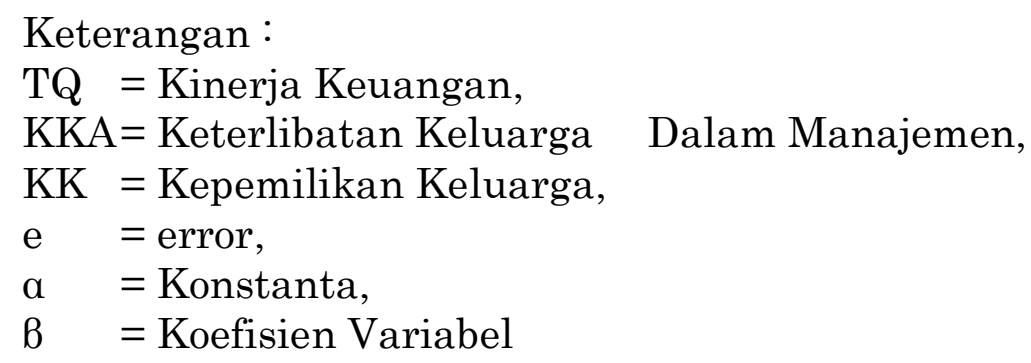

Dalam penelitian ini digunakan uji asumsi klasik. Pengujian asumsi klasik bertujuan untuk menentukan ketepatan model. Uji asumsi klasik yang akan digunakan dalam penelitian ini meliputi: Uji Normalitas, Uji Heteroskedastisitas, Uji Autokorelasi, dan Uji Multikolinieritas.

\section{HASIL DAN PEMBAHASAN \\ Data Deskriptif}

Penelitian ini dilakukan untuk menguji pengaruh keterlibatan keluarga dalam manjemen (KKA) dan Kepemilikan Keluarga (KK) terhadap kinerja keuangan di Indonesia. Kinerja keuangan perusahaan dalam penelitian ini menggunakan variabel Tobin $Q$. Data yang digunakan dalam penelitian ini adalah data sekunder yang bersumberdari ICMD (Indonesia Capital Market Directory) tahun 2010-2013. Pengumpulan sampel dilakukan dengan metode purposive sampling dengan tujuan untuk mendapatkan sampel yang sesuai 
dengan kriteria perusahaan yang dibutuhkan. Kriteria yang digunakan yaitu perusahaan keluarga yang telah go public di pasar modal tahun 2010-2013. Dalam empat tahun terakhir tersebut berturut-turut memiliki data keterlibatan keluarga dalam manajemen dan kepemilikan saham keluarga. Jumlah perusahaan yang diteliti yaitu 8 perusahaan. Penelitian ini menggunakan data perusahaan keluarga yang terdaftar selama 2010-2013, dengan demikian ada 32 observasi. Seluruh analisis data yang dilakukan pada bagian ini menggunakan program Statistical Package for the Social Software (IBM SPSS 21.0).

\section{Tabel 1. Hasil Statistik Deskriptif}

\begin{tabular}{cccccc}
\hline & $\begin{array}{c}\mathrm{N} \\
\text { Statistic }\end{array}$ & $\begin{array}{c}\text { Minimum } \\
\text { Statistic }\end{array}$ & $\begin{array}{c}\text { Maximum } \\
\text { Statistic }\end{array}$ & $\begin{array}{c}\text { Mean } \\
\text { Statistic }\end{array}$ & $\begin{array}{c}\text { Std. Deviation } \\
\text { Statistic }\end{array}$ \\
\hline Tobinq & 32 & .0238362 & 3.0437330 & .611435812 & .5393044733 \\
KKA & 32 & .1428571 & .5000000 & .225502622 & .0930740735 \\
KK & 32 & .0004000 & .4640000 & .131962500 & .1405246913 \\
Valid N & 32 & & & & \\
(listwise) & & & & & \\
\hline
\end{tabular}

Sumber : Hasil pengolahan data penelitian.

Hasil output tampilan SPSS menunjukkan jumlah observasi (N) sebanyak 32, dari 32 observasi ini Kinerja keuangan (Tobin Q) nilai terkecil (minimum) 0.0238 nilai terbesar (maximum) sebesar 3.0437 dan nilai mean 0.6114. Keterlibatan keluarga dalam manajemen (KKA) nilai terkecil (minimum) sebesar 0.1428, nilai terbesar (maximum) sebesar 0.5000, dan nilai mean sebesar 0.2255. Kepemilikan Keluarga (KK) memiliki nilai terkecil (minimum) sebesar 0.0004, nilai terbesar (maximum) sebesar 0.4640, dan nilai mean sebesar 0.1319 .

\section{Hasil Penelitian}

Untuk menguji normalitas residual digunakan alat kolmogorov-smirnov. Berdasarkan hasil uji normalitas residual menunjukan bahwa dalam penelitan ini residual berdistribusi secara normal karena nilai probabilitas KolmogorovSmirnov 1.325, prob = 0,06 lebih besar dari tingkat signifikan sebesar 5\%. Maka dapat disimpulkan $\mathrm{H}_{0}$ diterima.

Uji autokorelasi untuk menguji ada tidaknya korelasi antara kesalahan pengganggu pada periode $t$ dengan kesalahan pengganggu pada periode $t-1$ (sebelumnya). Uji Autokorelasi bertujuan menguji apakah dalam model regresi linear ada korelasi antara kesalahan pengganggu pada periode $t$ dengan kesalahan pengganggu pada periode t-1 (sebelumnya). Jika terjadi korelasi, maka dinamakan ada problem Autokorelasi. Data dinyatakan tidak ada autokorelasi jika berada di atas $\geq 5 \%$ (Ghozali, 2011). Dari hasil perhitungan di atas diperoleh nilai Durbin-Wastonnya (D-W) sebesar 2.188 dengan jumlah data yang digunakan 32 dengan tabel signifikasi 5\%. Dari table DurbinWastonnya (D-W) diketahui nilai dl sebesar 1,309 dan du sebesar 1,574 maka nilai yang dihasilkan dl sebesar $4-(1,309)=2.691$ dan du 4-(1,574)=2,426. Dengan demikian, dapat ditarik kesimpulan bahwa tidak ada autokolerasi pada 
model data di atas.

Uji heteroskedastisitas dilakukan untuk menguji ada tidaknya ketidaksamaan varian dari residual satu pengamatan ke pengamatan yang lain dalam model regresi. Salah satunya dengan menggunakan uji Glejser, sehingga dengan menggunakan uji glejser dengan menggunakan variabel dependen Absres tidak ditemukan adanya masalah heteroskedastisitas karena nilai semua koefisien $B$ kedua variabel independen $\geq 5 \%$. Dengan demikian penelitian ini lolos uji heterokedastisitas.

Uji multikolinearitas bertujuan untuk menguji apakah dalam suatu model regresi ditemukan adanya korelasi antar variabel bebas (independen). Dari hasil uji multikolinearitas menunjukkan bahwa tidak ada nilai Tolerance variabel independen yang kurang dari 0.10 dan tidak ada nilai VIF variabel independen yang lebih besar dari 10.00. Untuk variabel KKA dan KK nilai tolerance sebesar 0.984 dimana nilai ini $<10 \%$ dan nilai VIF dari variabel KKA dan KK sebesar 1.017 dimana nilainya $>10$ Jadi, dapat disimpulkan tidak terjadi multikolinearitas dalam model regresi.

\section{Hasil Pengujian Hipotesis}

Pengujian hipotesis pada penelitian ini menggunakan analisa model regersi linear berganda, dengan Uji t. Hasil pengujian Uji t di sajikan pada tabel 2. Tabel 2 menunjukkan hasil regresi antara variabel dependen (Tobin Q) dengan variabel Independen (KKA dan KK). Hasilnya didapatkan bahwa variabel Independen KKA (Kepemilikan Keluarga Aktif) memiliki koefisien beta negatif sebesar -0,343, namun tidak signifikan ( $p$-value $=0,3695>a 0,05$ ). Dengan demikian dapat disimpulkan bahwa KKA tidak berpengaruh terhadap Tobin Q. Variabel KK (Kepemilikan Keluarga) memiliki koefisien beta negatif sebesar -1,332 dengan tingkat signifikan ( $p$-value $=0,029<\alpha 0,05)$. Hasil ini menunjukkan bahwa ketika KK semakin meningkat akan menurunkan kinerja perusahaan. Dengan demikian dapat disimpulkan bahwa KK berpengaruh negatif terhadap Tobin $\mathrm{Q}$.

Tabel 2. Hasil Uji Hipotesis

\begin{tabular}{lcc}
\hline Variabel & B & Sig \\
\hline $\begin{array}{l}\text { Variabel Independen } \\
\text { Keterlibatan Keluarga } \\
\text { dalam Manajemen (KKA) }\end{array}$ & $-0,343$ & 0,3695 \\
$\begin{array}{l}\text { Kepemilikan Keluarga } \\
\text { (KK) }\end{array}$ & $-1,332$ & 0,029 \\
\hline Adj R^2 & 0,058 \\
\hline \multicolumn{2}{l}{ Sumber : Hasil pengolahan data penelitian }
\end{tabular}

Sumber : Hasil pengolahan data penelitian

\section{PEMBAHASAN}

\section{Pengaruh Keterlibatan Keluarga terhadap Kinerja Keuangan}

Hasil pengujian hipotesis pertama menunjukan bahwa Keterlibatan keluarga dalam manajemen (KKA) memiliki koefisien negatif dan tidak signifikan terhadap kinerja perusahaan (Tobin Q). Hasil ini mengindikasikan bahwa keterlibatan keluarga justru menurunkan kinerja keuangan 
perusahaan. Dalam hal ini, kerterlibatan keluarga dalam manejemen justru menurunkan kinerja keuangan perusahaan. Dalam hal ini mereka cenderung mengambil keuntungan pribadi dari perusahaan. Meskipun demikian, keterlibatan keluarga tidak signifikan, bisa jadi karena belum banyak keluarga yang terlibat dalam manajemen perusahaan. Hasil ini tidak mendukung penelitian Andres (2008), yang menyatakan bahwa apabila keluarga hanya bertindak sebagai pemegang saham dan tidak aktif dalam pengelolaan perusahaan, maka kinerja perusahaan menjadi buruk. Namun jika anggota keluarga berpartisipasi dalam kegiatan manajerial, maka kinerja perusahaan akan meningkat. Dilain pihak, penelitian ini mendukung pendapat Anderson dan Reeb (2004) menunjukkan bahwa keterlibatan keluarga dalam manajemen dan dalam dewan direksi berpengaruh negatif pada kinerja perusahaan di Indonesia. Dengan demikian penelitian ini tidak berhasil mendukung $\mathrm{H}_{1}$ yang menyatakan bahwa keterlibatan keluarga dalam manajemen berpengaruh positif terhadap kinerja perusahaan.

\section{Pengaruh kepemilikan keluarga terhadap kinerja keuangan}

Hasil pengujian hipotesis ke dua menunjukkan bahwa Kepemilikan Keluarga (KK) berpengaruh negatif terhadap kinerja perusahaan (Tobin Q). Meskipun variabel ini berpengaruh terhadap kinerja keuangan tetapi hasil ini tidak mendukung arah hipotesis kedua $\left(\mathrm{H}_{2}\right)$. Hasil ini tidak mendukung perspektif teori Efek Alignment. Namun demikian, hasil ini mengindikasikan bahwa pengendalian keluarga melalui kepemilikan keluarga ini berdampak pada penurunan kinerja keuangan perusahaan. Dalam hal ini bisa jadi perusahaan yang dikendalikan oleh keluarga cenderung mempunyai kepentingan pribadi yang bertentangan dengan pemilik saham minoritas. Pemilik keluarga akan berusaha mensejahterakakan keluarganya sendiri dan lebih mengutamakan dana yang mereka investasikan kedalam perusahaan dibandingkan dengan memikirkan kinerja dari perusahaan yang di investasikan.

Hasil penelitian yang demikian itu, sejalan dengan pandangan teori entrenchment effect, yang menyatakan bahwa kepemilikan keluarga akan membuat keluarga membentuk perkubuan untuk mengambil keuntungan pribadi di dalam perusahaan, sehingga adanya kepemilikan keluarga menurunkan kinerja perusahaan. Penelitian ini mendukung pendapat Cucculelli and Micucci (2008) yang menemukan kepemilikan saham keluarga yang besar mempunyai pengaruh negatif bagi kinerja perusahaan. Hal ini terjadi karena keluarga cenderung mengambil manfaat pribadi dari perusahaan dengan semakin banyak nilai saham yang di investasikan maka semakin mudah untuk mengendalikan perusahaan. Ketika timbul suatu resiko yang sangat tinggi yang dialami oleh perusahaan, maka pemilik akan cenderung lebih menyelamatkan uang yang mereka investasikan dari pada memperbaiki kinerja perusahaan.

\section{PENUTUP}

Berdasarkan hasil penelitian dan pembahasan, dapat disimpulkan beberapa hal. Pertama, kepemilikan keluarga (KK) berpengaruh negatif terhadap kinerja keuangan. Hasil ini tidak sejalan dengan harapan perspektif 
teori Efek Alignment. Namun sebaliknya hasil penelitian, cenderung mendukung prediksi teori entrenchment effect. Hal ini konsisten dengan pernyataan Cucculelli and Micucci (2008) menemukan kepemilikan saham keluarga yang besar mempunyai pengaruh negatif bagi kinerja perusahaan. Kedua, penelitian ini menunjukkan bahwa keterlibatan keluarga dalam manajemen tidak berpengaruh negatif terhadap kinerja keuangan. Penemuan ini tidak mendukung penelitian yang dilakukan Anderson dan Reeb (2003); Demsetz dan Villangola (2004); Maury (2006) menyatakan bahwa kontrol keluarga dapat meningkatkan kinerja perusahaan melalui kepemilikan yang aktif yaitu dengan menempati setidaknya salah satu posisi teratas

\section{REFERENSI}

Anderson, R. C., and Reeb, D. M. 2003. Founding-Family Ownership and Firm Performance: Evidence from the S\&P 500. Journal of Finance, 58, 1301-1328.

Andres, C. 2008. Large shareholders and firm performance: An empirical examination of founding family ownership. Journal of Corporate Finance, 14(4): 431-445

Maury, B. 2006. Family ownership and firm performance: Empirical evidence from Western European corporations. Journal of Corporate Finance, 12 (2): 321- 341.

Claessens, S., Djankov, S., Fan, J.P.H. and Lang, L.H.P. 2002 Disentangling the incentive and entrenchment effects of large shareholdings. Journal of Finance, 57(6): 27412771.

Chung, H. Kee., dan Pruitt, W. Stephen. 1994. A Simple Approximation of Tobin's Q. Financial Management, Vol.23, No.3, Autumn 1994, pages 70-74.

Cucculelli, M. and Micucci, G. 2008. Family Succession and Firm Performance. Evidence from Italian Companies, Journal of Corporate Finance, 14(1).

Demsetz, H. and Villalonga, B. 2001, Ownership structure and corporate performance, Journal of Corporate Finance, 7, 209-33.

Fan, J. P. H. Dan T. J. Wong. 2002. Corporate Ownership Structure and the Informativeness of Accounting Earnings in East Asia. Journal of Accounting and Economics, 33: 133152.

Ghozali, I. 2011. Aplikasi Analisis Multivariate dengan program SPSS. Semarang: Universitas Diponegoro.

Jensen, M. C. and William H. M. 1976. Theory of The Firm: Managerial Behavior, Agency Costs and Ownership Structure. Journal of Financial Economics, 3, 305-360.

Kowalewski, O., Talavera, O. and Stetsyuk, I. 2010. Influence of Family Involvement in Management and Ownership on Firm Performance: Evidence From Poland. Family Business Review, 23(1): 45-59

La Porta, R., F. Lopez-de-Silanez, and A. Shleifer, 1999. Corporate Ownership around the World, Journal of Finance, 54, 1116-1132.

Mishra, C.S. and McConaughy, D. L. 1999. Founding Family Control and Capital Structure: The Risk of Loss of Control and the Aversion to Debt. Entrepreneurship Theory And Practice, 23(4): 53-64

Rusmin, R., Tower, G., Achmad, T. and Neilson, J. 2011. Concentrated Family Ownership Structures Weakening Corporate Governance: A Developing Country Story. Corporate Ownership \& Control, 8 (2): 96-107

Villalonga, B. and Amit, R. 2006. "How do family ownership control and management affect firm value?” Journal of Financial Economics, Vol. 80, pp. 385-417.

Widjaja, F. dan Ronny, H. 2014. Pengaruh Sistem Pengendalian Internal Terhadapimplementasi Prinsip - Prinsip Good Corporate Governance pada Perusahaan Industri Keramik. Agora, Vol. 2, No. 1, (2014). 